\title{
TRANSPORT OF AMINO ACIDS IN INTACT 3T3 AND SV3T3 CELLS. Binding Activity for Leucine in Membrane Preparations of Ehrlich Ascites Tumor Cells
}

\author{
Gary Cecchini, Mary Lee, and Dale L. Oxender \\ Department of Biological Chemistry, Medical Science I, The University of Michigan, \\ Ann Arbor, Michigan
}

\begin{abstract}
Transport of amino acids into $3 \mathrm{~T} 3$ and SV3T3 (SV40 virus-transformed 3T3) cells was measured on glass cover slips. The 3T3 and SV3T3 cells contain both A (alanine preferring) and $\mathrm{L}$ (leucine preferring) systems for neutral amino acid transport. Initial rates of uptake of amino acids are about twofold higher in SV3T3 than in 3T3 cells. Other parameters measured, however, do not indicate marked differences in the transport of amino acids by the two cell types. L-system amino acids, such as leucine, are subject to trans-stimulation in both cell lines, whereas A-system amino acids, such as alanine and glycine, are not. Leucine was transported to higher levels in confluent cells than in nonconfluent cells. Glycine, however, shows distinctly less transport activity as the cells become confluent.

Ehrlich ascites cell plasma membranes were prepared and assayed for amino acid-binding activity. Leucine-binding activity was detected by equilibrium dialysis in Triton X-100-treated membrane preparations.
\end{abstract}

\section{INTRODUCTION}

It has been suggested that the growth of mammalian cells may be regulated by the availability of nutrients inside the cell $(1,2)$. In addition it was proposed that a crucial change in a malignant cell is an alteration in the cell membrane resulting in increased internal concentrations of nutrients (2).

Early studies of neutral amino acid transport in Ehrlich cells have suggested that there are two distinct but heavily overlapping transport systems (3). These systems have been referred to as the $\mathbf{L}$ system (leucine preferring) and A system (alanine preferring). In the present study, we examined the amino acid transport systems of 3T3 mouse cells and determined the effect of transformation on these transport systems. In addition, membrane preparations from Ehrlich ascites cells were determined to have leucinebinding activity.

\section{METHODS}

The 3T3 and simian virus (SV40)-transformed 3 T3 cells (referred to as SV3T3) were obtained from Dr. G. J. Todaro of the National Cancer Institute. Both cell lines were free of mycoplasma infection as determined by uridine phosphorylase activity (4). 
The cell lines were cultured in Dulbecco's modified Eagle's medium (5) adjusted so that a $\mathrm{pH}$ of 7.4 would be obtained when the medium was equilibrated in a $5 \% \mathrm{CO}_{2}$ atmosphere. In addition to penicillin and streptomycin at concentrations of 120 units and $120 \mu \mathrm{g}$ per ml, respectively, the growth medium was supplemented with $10 \%$ calf serum obtained from Gibco.

Transport was measured on glass cover slips by techniques similar to that described by Foster and Pardee (6). The cultured cells were rinsed three times in phosphate-buffered salt solution (PBS) with $0.1 \%$ glucose and $0.001 \% \mathrm{CaCl}_{2}$ and $\mathrm{MgCl}_{2}$ (PBSG). The cells were depleted in PBSG for $30 \mathrm{~min}$ at $30^{\circ} \mathrm{C}$ prior to measurement of transport activity. After depletion, the cover slips were incubated for a specified period of time in PBSG plus amino acid and then rinsed three times in PBSG at $0^{\circ} \mathrm{C}$. Each cover slip was then placed in $0.6 \mathrm{ml}$ of $0.2 \mathrm{~N} \mathrm{NaOH}$ and a sample removed for counting in a scintillation counter and another sample used for protein determination by the method of Lowry (7).

Labeled amino acids were obtained from New England Nuclear. All other compounds were of reagent grade.

\section{RESULTS}

Time courses for uptake of L-leucine by confluent 3T3 and SV3T3 cells are shown in Fig. 1. The SV3T3 cells show a higher uptake of leucine than do 3T3 cells at $10 \mathrm{~min}$. The initial rate of leucine entry is also more rapid in SV3T3 cells than in 3T3 cells. Similar increases in initial rates were observed when A-system amino acids, such as alanine or glycine, were examined for their rate of uptake (data not shown).

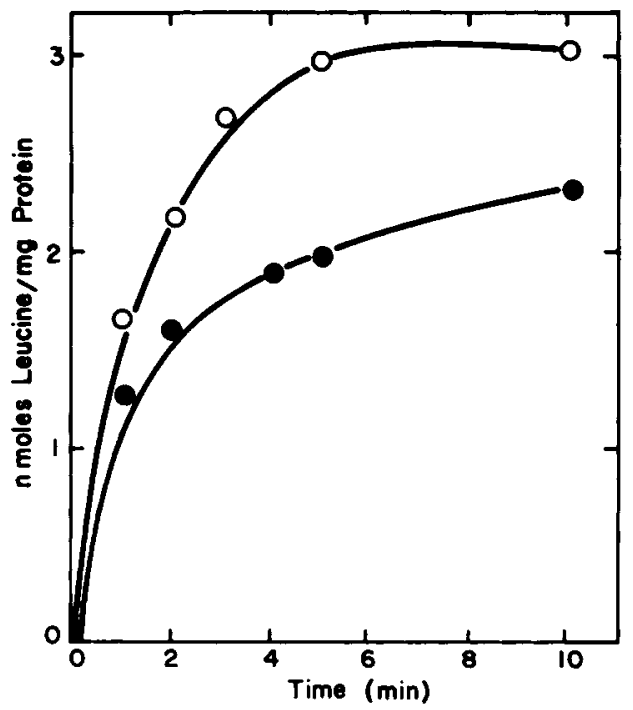

Fig. 1. Time course of the uptake of leucine by confluent 3T3 cells (closed symbols) and confluent SV3T3 cells (open symbols) on glass cover slips. The concentration of leucine in the incubation medium was $0.1 \mathrm{mM}$. Each point represents the average of duplicate determinations of uptake. Inclusion of $10 \mu \mathrm{g} / \mathrm{ml}$ of cycloheximide during depletion had no effect on uptake. 
Results of a typical experiment in which the initial rate of leucine uptake in confluent 3 T 3 and SV3T3 cells was measured at different substrate concentrations are shown in Fig. 2. A number of experiments of this type were performed utilizing confluent cells and various amino acids (data not shown). Analysis of the data by the double reciprocal method always showed distinctly biphasic plots for leucine uptake by $3 \mathrm{~T} 3$ cells. However, the biphasic nature of the kinetic plots was not readily apparent for leucine transport in SV3T3 cells. Biphasic plots have often been observed for amino acid transport systems in mammalian cells $(3,8)$. In Table I the kinetic constants for leucine and glycine uptake for 3T3 and SV3T3 cells are presented. These data appear to show a difference in $\mathrm{K}_{\mathrm{m}}$ values but no significant changes in the $\mathrm{V}_{\max }$ value for the amino acid transport systems when cells are transformed by SV40 virus. Leucine shows an apparent low $\mathrm{K}_{\mathrm{m}}$ value as well as a high $\mathrm{K}_{\mathrm{m}}$ component in $3 \mathrm{~T} 3$ cells as obtained from a double reciprocal plot. The $\mathrm{K}_{\mathrm{m}}$ for glycine transport is about sixfold lower in SV3T3 cells than that obtained from $3 \mathrm{~T} 3$ cells. The $\mathrm{V}_{\max }$ for A-system amino acids, such as glycine, is usually 10-40-fold higher than for L-system amino acids, such as leucine. The higher capacity of the A system was observed for both cell types.

The effect of cell density on amino acid transport activity for the L-system is different from that found for the A-system. As shown in Fig. 3, transport activity increases for leucine as cells approach confluency, however, glycine transport decreases as cells approach confluency. The same results were observed for SV3T3 cells (data not shown).

Preloading the cells with leucine during the depletion procedure produces a stimulation of leucine uptake. Figure 4 shows that a three- to fourfold increase in leucine transport is obtained in cells preloaded with leucine. In contrast to these results, no stimulation of glycine transport is obtained by preloading cells with glycine. This observation is similar to results previously reported for Ehrlich ascites cells (3).

Utilizing a large number of amino acids and amino acid analogs for inhibition studies, it was possible to show that 3T3 and SV3T3 cells possess an A and an L system for transport of the neutral amino acids (data not shown). The data for 3T3 and SV3T3 cells are qualitatively similar to that observed in Ehrlich ascites cells (3). In addition, no obvious differences in the transport systems for amino acids were seen in 3T3 and SV3T3 cells.

\section{Amino Acid Binding Activity from Membrane Preparations from Ehrlich Ascites Cells}

Plasma membrane fractions have been prepared from Ehrlich cells by a modification of the method of Forte et al. (9). Washed cells were suspended in $15 \mathrm{mM} \mathrm{NaPO}_{4}$ buffer ( $\mathrm{pH}$ 7.4) with $1 \mathrm{mM} \mathrm{MgCl} 2$. The cell suspension was disrupted with a Dounce homogenizer and differential centrifugation gave a membrane fraction 10 -fold purified with respect to $\mathrm{Na}^{+}-\mathrm{K}^{+}$ATPase. Final purification utilized a 40-60\% stepwise sucrose gradient at $25,000 \mathrm{rpm}$ in an SW27 rotor. A plasma membrane fraction 25-30-fold enriched for $\mathrm{Na}^{+} \cdot \mathrm{K}^{+}$ATPase banded at the $40-45 \%$ sucrose interface. It may be seen in Table II that in the presence of Triton X-100, saturable leucine-binding activity can be measured in this plasma membrane preparation. The binding activity is not present in the absence of the detergent. The specificity of the binding activity is as would be expected for Ehrlich cells since phenylalanine also saturates the binding activity. 
TABLE I. Kinetic Constants for Uptake of Leucine and Glycine by $3 T 3$ and SV3T3 Cells at Confluency

\begin{tabular}{cccccc} 
& \multicolumn{3}{c}{ Substrate } & Glycine \\
\cline { 2 - 5 } Cell line & Apparent $\mathrm{K}_{\mathrm{m}}$ & Apparent $\mathrm{V}_{\max }$ & & Apparent $\mathrm{K}_{\mathrm{m}}$ & Apparent $\mathrm{V}_{\mathrm{max}}$ \\
\hline \multirow{2}{*}{$3 \mathrm{~T} 3$} & 6 & 1.1 & 500 & 12 \\
& 91 & 0.3 & & 16 \\
SV3T3 & 12 & 1.0 & 80 & 16 \\
\hline
\end{tabular}

The kinetic constants were determined from double reciprocal plots. Experimental conditions were as described in the text and in the legend to Fig. $2 . \mathrm{K}_{\mathrm{m}}$ is in $\mu \mathrm{M}$ and $V_{\max }$ is expressed as nmoles per min per $\mathrm{mg}$ protein.

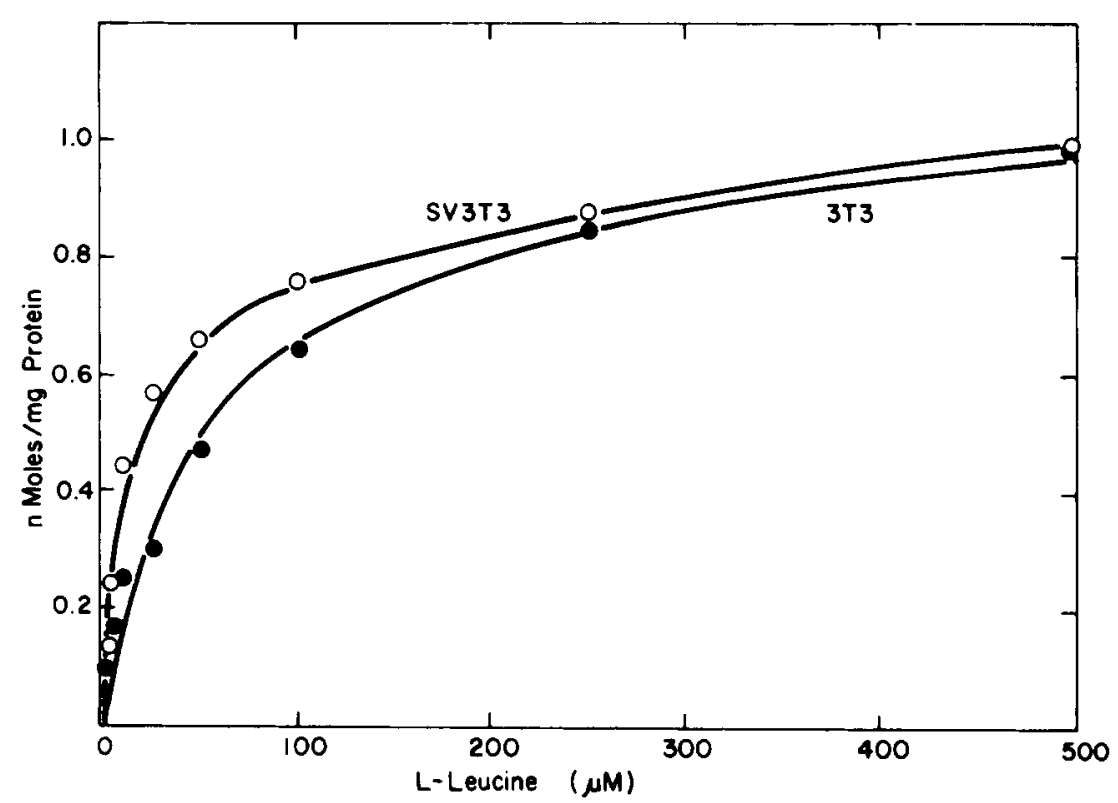

Fig. 2. Velocity of leucine uptake plotted against leucine concentration for 3T3 (closed symbols) and SV3T3 cells (open symbols). Cells were confluent and incubations were for $1 \mathrm{~min}$, which gives initial rates under these conditions. Each point represents the average of duplicate determinations of uptake.

\section{DISCUSSION}

The present investigation was initiated to examine amino acid transport in 3T3 cells and to determine whether transformation resulted in alteration of transport capability. Alterations in mammalian plasma membranes have been shown following transformation; therefore, one might expect to find differences in transport capability. Sugar transport increases have been reported following transformation (10). However, the data reported here do not show marked changes in amino acid transport following SV40 transformation. 


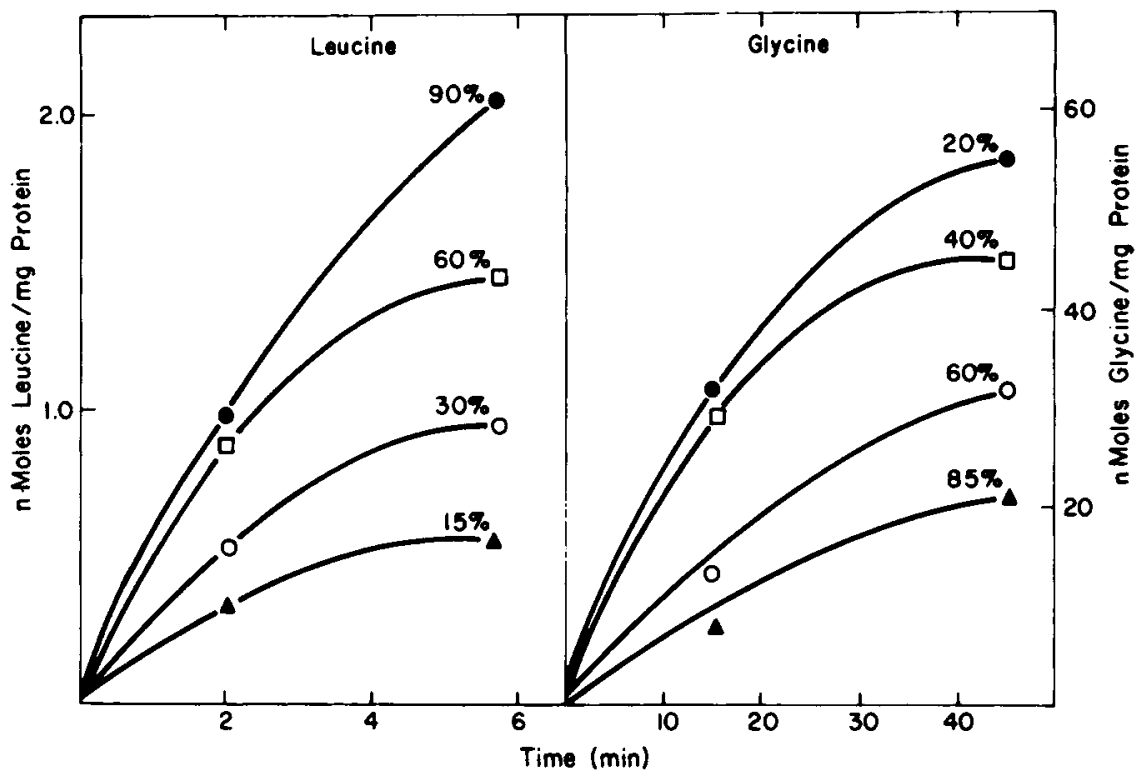

Fig. 3. Uptake of leucine (left panel) and glycine (right panel) with $3 \mathrm{~T} 3$ cells at different densities on glass cover slips. Cells were inoculated at $0.1 \times 10^{5}$ cell $/ \mathrm{ml}$. Cult ures were allowed to grow, and transport and protein determinations were made for each cover slip. When visual observations indicated the cells were confluent, protein was determined and this value given $100 \%$ confluency. Protein values from previously assayed samples were compared to this value to assign percent confluency. Each point represents the results of duplicate determinations. Leucine and glycine concentrations were $0.05 \mathrm{mM}$.

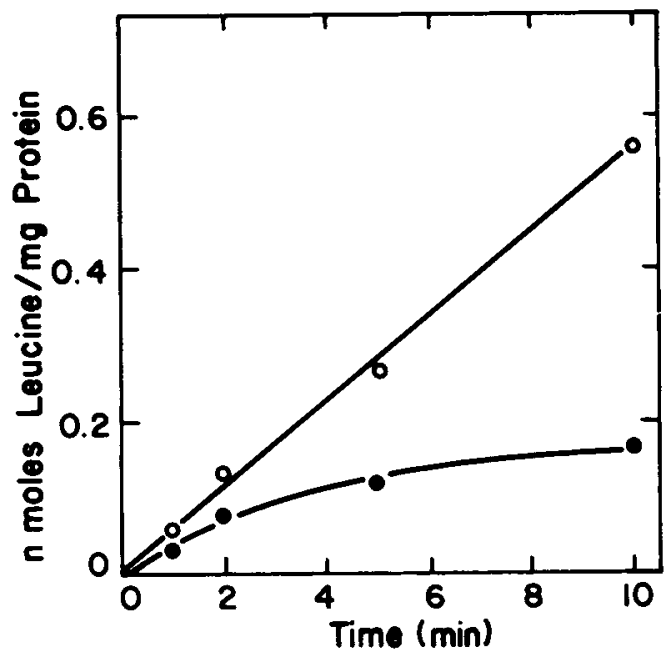

Fig. 4. Effect of preloading the cells on rate of leucine uptake in $3 T 3$ cells. Time course of leucine uptake in depleted cells (closed symbols). The $3 \mathrm{~T} 3$ cells were preloaded for $30 \mathrm{~min}$ with $1 \mathrm{mM}$ leucine in the depletion media and then uptake was determined as usual after dipping the cover slip three times in PBSG (open symbols). Uptake in both cases was with $0.05 \mathrm{mM}$ leucine. 
TABLE II. Leucine Binding Activity in Ehrlich Cell Plasma Membrane Fractions

\begin{tabular}{lcc} 
& \multicolumn{2}{c}{ Ratio in/out } \\
\cline { 2 - 3 } (-) Triton X-100 & (t) Triton X-100 \\
$50 \mu$ M leucine & 0.99 & 1.35 \\
$50 \mu$ M phenylalanine & 1.00 & 1.01 \\
with 1 nM leucine & 0.96 & 1.01 \\
\hline
\end{tabular}

Binding activity was measured by equilibrium dialysis in the absence or presence of $(0.5 \% \mathrm{v} / \mathrm{v})$ Triton X-100. Binding was measured at $4^{\circ} \mathrm{C}$ after $32 \mathrm{hr}$ of dialysis in $15 \mathrm{mM} \mathrm{NaPO}_{4}, \mathrm{pH} 7.4$, with $0.001 \% \mathrm{CaCl}_{2}$ and $\mathrm{MgCl}_{2}$. Protein concentration was $1.1 \mathrm{mg}$ in the dialysis chamber. Activity is expressed as the ratio of cpm inside (membrane fraction) to outside (buffer with amino acid). Sodium azide $(0.03 \%)$ is included in all dialysis solutions.

SV3T 3 cells do have a two- to threefold increase in the initial rate of uptake of leucine. However, the $\mathrm{V}_{\max }$ is not markedly different for any of the amino acids so far examined. Also, the effect of inhibitors preloading, and cell density did not appear to be markedly different in 3 T3 or SV3T3 cells. The failure to find marked differences in amino acid transport following transformation may reflect alterations that $3 \mathrm{~T} 3$ cells have previously undergone in differentiation from a primary to secondary cell line.

The results show that the transport-mediating systems for the amino acids in 3T3 cells are of two general types, the $\mathrm{A}$ and $\mathrm{L}$ systems, which are similar to that previously described for other mammalian cells (3). Leucine is stimulated by preloading, however, no stimulation is observed with glycine. This would indicate that the L-system is largely an exchanging system, whereas the A-transport system is less reversible.

We have observed a difference in the effect of cell confluency on the ability to transport leucine and glycine. These results are somewhat different from those previously reported (6). The basis for the stimulation of leucine uptake and the reduction of glycine uptake upon the attainment of confluency is under investigation.

Binding activity for leucine has been observed in plasma membranes of Ehrlich cells. The activity is found only in the presence of detergents, although the activity does not appear to be completely solubilized. The specificity of the binding activity is similar to that observed for the $\mathrm{L}$ transport system in 3T3 and Ehrlich cells (3). The binding activity is saturable with high concentrations of leucine. Purification of the binding activity is in progress.

\section{ACKNOWLEDGMENTS}

The help of WhaBin Im in the preparation of plasma membranes is greatly appreciated. This research was supported by the National Institutes of Health, grant GM 20737. 


\section{REFERENCES}

1. Pardee, A. B., Natl. Cancer Inst. Monogr. 14:7 (1964).

2. Holley, R. W., Proc. Natl. Acad. Sci. 69:2840 (1972).

3. Oxender, D. L., Christensen, H. N., J. Biol. Chem. 238:3686 (1963).

4. Levine, E. M., Exp. Cell Res. 74:99 (1972).

5. Smith, J. D., Freeman, G., Vogt, M., and Dulbecco, R., Virology 12:185 (1960).

6. Foster, D. O., and Pardee, A. B., J. Biol. Chem. 244:2675 (1969).

7. Lowry, O. H., Rosebrough, N. J., Farr, A. L., and Randall, R. J., J. Biol. Chem. 193:265 (1951).

8. Hillman, R. E., and Otto, E. L., J. Biol. Chem. 249:3430 (1974).

9. Forte, J. G., Forte, T. M., and Heinz, E., Biochim. Biophys. Acta 298:827 (1973).

10. Kletzien, R. F., and Perdue, J. F., J. Biol. Chem. 249:3375 (1974). 